\title{
POTENSI TEPUNG KENTANG HITAM (Coleus tuberosus) SEBAGAI PENSUBSTITUSI TERIGU PADA PEMBUATAN CAKE
}

\author{
[Potential of Black Potato Flour (Coleus tuberosus) as Wheat Substition Of Cake]
}

\author{
Siska Cicilia*, Eko Basuki, Agustono Prarudiyanto, Ahmad Alamsyah, Dody Handito \\ Program Studi Ilmu dan Teknologi Pangan, Fakultas Teknologi Pangan dan Agroindustri, Universitas Mataram \\ *email: siskacicilia@unram.ac.id
}

Diterima 9 Juli 2018/ Disetujui 27 Oktober 2018

\begin{abstract}
Wheat flour is one type of flour that was often used for making various types of foods and dishes such as noodles, bread, biscuits, cakes, cookies, and porridge. Availability of wheat flour supplied from imports. The high demand for wheat flour because of the increasing needs of the food industry. Dependence on wheat flour can have a negative impact on the country's economy. One alternative wheat substitution is tubers such as black potatoes. The purpose of this study was to figure the best formulation in making cakes from wheat flour and black potato flour. The results showed that the more addition of black potato flour caused a decrease in moisture content, increase in ash content and protein levels and a decrease in the level of preference of panelists. Adding potato flour to $10 \%$ produces a cake that preferred by panelists.
\end{abstract}

Keywords: cake, Coleus tuberosus, wheat substitution

\begin{abstract}
ABSTRAK
Tepung terigu merupakan salah satu jenis tepung yang sering digunakan dalam membuat berbagai jenis makanan dan masakan seperti mie, roti, biskuit, cake, cookies, dan bubur. Ketersediaan tepung terigu disuplai dari impor. Tingginya permintaan tepung terigu karena kebutuhan industri makanan yang terus meningkat. Ketergantungan terhadap tepung terigu bisa berdampak buruk terhadap perekenomian negara. Salah satu alternatif pengganti terigu adalah tepung umbbi-umbian seperti kentang hitam. Tujuan penelitian ini adalah menentukan formulasi terbaik dalam pembuatan cake dari tepung terigu dan tepung kentang hitam. Hasil penelitian menunjukkan semakin banyak penambahan tepung kentang hitam menyebabkan penuruan kadar air, penngkatan kadar abu dan kadar protein serta penurunan tingkat kesukaan panelis. Penambahan tepung kentang hingga 10\% menghasilkan cake yang disukai panelis.
\end{abstract}

Kata Kunci : cake, kentang hitam, substitusi terigu

\section{PENDAHULUAN}

Tepung terigu dalah tepung yang berasal dari gandum dengan beberapa tahap pengolahan. Tepung terigu merupakan salah satu jenis tepung yang sering digunakan dalam membuat berbagai jenis makanan dan masakan seperti mie, roti, biskuit, cake, cookies, dan bubur. Fungsi tepung terigu adalah untuk membentuk adonan menjadi stabil, mempunyai struktur, mengikat bahan lain dan membantu mencampur bahan-bahan lain secara merata (Ikrawan, 2006). Dalam pembuatan roti diperlukan tepung terigu yang memiliki glutein tinggi (glutein 12-14\%) sedangkan pada pembuatan cake dan biskuit diperlukan tepung terigu dengan glutein rendah (9-10\%).

Konsumsi tepung terigu Indonesia semakin meningkat setiap tahunnya.
Ketersediaan tepung terigu disuplai dari impor. Menurut Asosiasi Produsen Tepung Terigu Indonesia (Aptindo) impor gandum diprediksi terus meningkat dan pada tahun 2017 menjadi sekitar 11,8 juta ton. Tingginya permintaan gandum antara lain terus terdorong oleh besarnya kebutuhan industri makanan dan pakan ternak yang terus meningkat. Ketergantungan terhadap tepung terigu bisa berdampak buruk terhadap perekenomian negara. Diperlukan alternatif pengganti tepung terigu seperti tepung dari kacang-kacangan dan umbi-umbian. Umbi yang memiliki potensi cukup untuk dikembangkan sebagai pengganti tepung terigu adalah kentang hitam.

Kentang hitam (Coleus tuberosus) merupakan salah satu jenis umbi-umbian yang memiliki karbohidrat yang cukup tinggi, indek 
Versi Online:

http://www.profood.unram.ac.id/index.php/profood e-ISSN: 2443-3446

glikemik yang rendah serta memiliki vitamin dan mineral penting. Kentang hitam memiliki karbohidrat sebesar 33,7 g/100 g; lebih tinggi daripada kentang dan ubi jalar yang memiliki karbohidrat sebesar 13,5 g/100 g dan 20,6 g/100 g (Persatuan Ahli Gizi Indonesia, 2009). Pemanfaatan kentang hitam oleh masyarakat masih sangat terbatas yaitu hanya diolah menjadi sayur atau dikonsumsi dengan pengolahan yang sangat sederhana.

Penelitian tentang pemanfaatan kentang hitam pada pengolahan pangan belum banyak dilakukan seperti roti tawar (Rahman, 2009), crackers (Nugraheni dkk, 2015), dan cookies (Cicilia dkk, 2018). Tujuan penelitian ini adalah menentukan formulasi terbaik dalam pembuatan cake dari tepung terigu dan tepung kentang hitam. Dengan diperolehnya formulasi terbaik maka membuka peluang pemanfaatan kentang hitam dalam pembuatan cake dan produk pangan lainnya sehingga dapat mengurangi ketergantungan masyarakat dan industri terhadap tepung terigu dengan menggunakan sumber pangan lokal.

\section{BAHAN DAN METODE}

\section{Alat dan Bahan}

Bahan utama yang digunakan adalah tepung terigu, kentang hitam, gula, telur, air, garam, susu, aquades, dan mentega. Peralatan yang digunkan adalah glassware, timbangan analitik, kompor gas, timbangan kasar, oven, destilator, ayakan 100 mesh, mixer, dan peralatan pembuatan cake.

\section{Metode}

Metode yang digunakan pada penelitian ini adalah metode eksprimental yang terdiri dari 6 aras dan diulang sebanyak 3 kali yaitu sebagai berikut:

$\begin{array}{ll}\mathrm{Ca}_{1}= & \begin{array}{l}\text { Tepung terigu } 100 \% \\ \mathrm{Ca}_{2}=\end{array} \\ & \begin{array}{l}\text { Tepung terigu } 90 \%: \text { tepung kentang } \\ \text { hitam } 10 \%\end{array} \\ \mathrm{Ca}_{3}=\quad \begin{array}{l}\text { Tepung terigu } 80 \%: \text { tepung kentang } \\ \text { hitam } 20 \%\end{array} \\ \mathrm{Ca}_{4}=\quad \begin{array}{l}\text { Tepung terigu } 70 \%: \text { tepung kentang } \\ \text { hitam } 30 \%\end{array} \\ \mathrm{Ca}_{5}=\quad \begin{array}{l}\text { Tepung terigu } 60 \%: \text { tepung kentang } \\ \text { hitam } 40 \%\end{array} \\ \mathrm{Ca}_{6}=\quad \begin{array}{l}\text { Tepung terigu } 50 \%: \text { tepung kentang } \\ \text { hitam } 50 \%\end{array}\end{array}$

\section{Proses Pembuatan Cake Kentang Hitam}

Tahapan pembuatan cake kentang hitam adalah sebagai berikut :

\section{Pencampuran I}

Bahan berupa gula, telur, SP, dan baking powder dicampur menggunakan mixer selama 5 menit hingga terbentuk adonan kuning pucat dan kaku.

\section{Pencampuran II}

Tepung sesuai perlakuan dimasukkan ke dalam adonan dan dicampur hingga homogen kemudian dimasukkan mentega yang sudah dilelehkan. Untuk memperbaiki aroma cake yang dihasilkan maka ditambahkan vanili.

\section{Pencetakan}

Adonan yang sudah homogen dicetak ke dalam wadah berbahan alumunium foil yang sudah diolesi mentega dan dilumuri tepung (tiap adonan seberat $35 \mathrm{~g}$ ).

\section{Pemanggangan}

Suhu pemanggangan pada cake $180^{\circ} \mathrm{C}$ selama 30 menit. Pemanggangan dilakukan menggunakan oven listrik

Diagram alir pembuatan cake kentang hitam dapat dilihat pada Gambar 1.

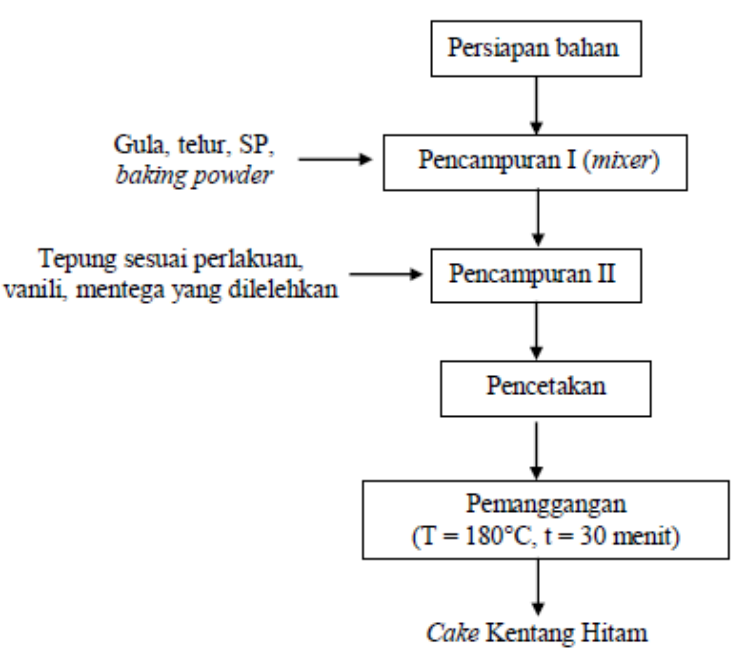

Gambar 1. Diagram Alir Pembuatan Cake Kentang Hitam

Parameter kimia meliputi, kadar air (metode termogravimetri), kadar abu (pengabuan kering), kadar lemak (metode soxhlet), dan kadar protein. Parameter organoleptik berupa rasa (hedonic), tekstur (hedonic), dan warna (scoring). 


\section{HASIL DAN PEMBAHASAN}

Hasil pengamatan dan analisa keragaman berikut uji lanjut untuk setiap parameter yang diamati dapat dilihat pada lampiran, sedangkan analisa keragaman parameter beserta uji lanjut dapat dilihat pada Tabel 1 dan Tabel 2 .

Tabel 1. Signifikansi Analisa Keragaman Beberapa Parameter Kimia Cake dari Tepung Terigu dan Tepung Kentang Hitam

\begin{tabular}{lc}
\hline \multicolumn{2}{c}{ Cake Kentang Hitam } \\
\hline Kadar Air (\%) & $67009,8 \mathrm{~S}$ \\
Kadar Abu (\%) & $52915,3 \mathrm{~S}$ \\
Kadar Protein (\%) & $416,1 \mathrm{~S}$ \\
\hline F tabel = 3,11 & \\
\hline \multicolumn{2}{l}{ Keterangan ; S = Signifikan (berbeda nyata) } \\
\multicolumn{2}{c}{ NS = Non Signifikan (tidak berbeda nyata) }
\end{tabular}

Tabel 2. Signifikansi Analisa Keragaman Beberapa Parameter Organoleptik Cookies dari Tepung Terigu dan Tepung Kentang Hitam

\begin{tabular}{lc}
\hline \multicolumn{2}{c}{ Cake Kentang Hitam } \\
\hline Warna (Scoring) & $75,2 \mathrm{~S}$ \\
Tekstur (Hedonic) & $5,2 \mathrm{~S}$ \\
Rasa (Hedonic) & $3,8 \mathrm{~S}$ \\
\hline F tabel = 2,19 & \\
\hline Keterangan ; S = Signifikan (berbeda nyata) \\
\multicolumn{1}{c}{ NS $=$ Non Signifikan (tidak berbeda nyata) }
\end{tabular}

\section{a Kadar Air}

Penentuan kadar air merupakan analisa penting dan paling luas dilakukan dalam pengolahan pangn karena berkaitan dengan kualitas bahan pangan. Kadar air sangat perlu diketahui dalam penentuan nilai gizi bahan pangan. Selain itu kadar air merupakan faktor yang sangat penting pada umur simpan bahan pangan tersebut, semakin tinggi kadar air bahan pangan maka semakin cepat mengalami kerusakan (Andarwulan dkk, 2011).

Berdasarkan analisa keragaman, perbedaan rasio penambahan tepung terigu dan tepung kentang hitam memberikan pengaruh yang berbeda nyata terhadap kadar air cake kentang hitam. Tingkat perbedaan kadar air akibat pengaruh penambahan tepung terigu dan
ISSN: 2443-1095

tepung kentang hitam dapat dilihat pada Gambar 2.

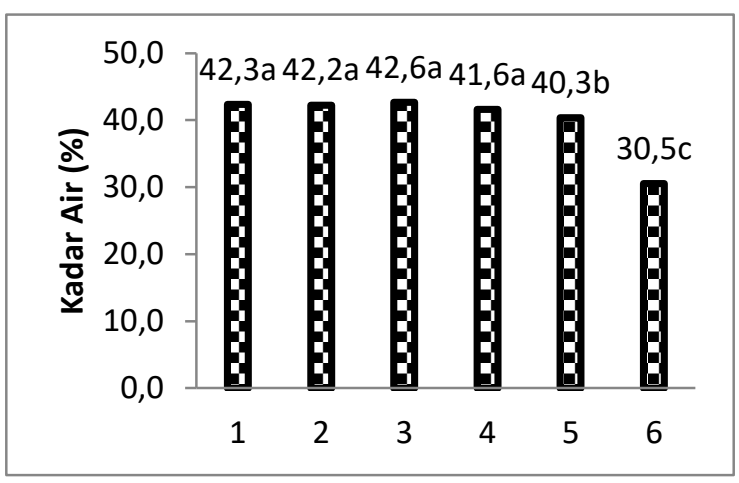

Gambar 2. Pengaruh Penambahan Tepung Terigu dan Tepung Kentang Hitam terhadap Kadar Air Cake Kentang Hitam

Berdasarkan Gambar 2 diketahui semakin sedikit tepung terigu yang ditambahkan maka kadar air cake semakin menurun. Kadar air terendah dihasilkan pada penambahan tepung terigu 50\%. Hal ini disebabkan semakin berkurangnya jumlah gluten dalam adonan cake yang berfungsi memperkuat material adonan (Rahmayuni dkk, 2013). Kadar air cake yang dihasilkan pada penelitian ini berkisar 30,5$42,6 \%$. Berdsarkan standar mutu cake (SNI 013840-1995) kadar air maksimun adalah 40\% sehingga hanya penambahan $50 \%$ tepung terigu dan $50 \%$ tepungkentang hitam yang memenuhi persyaratan SNI.

\section{b Kadar Abu}

Abu adalah residu anorganik dari proses pembakaran atau oksidasi komponen organik bahan pangan. Kadar abu total adalah bagian dari analisis proksimat yang bertujuan untuk mengevalusi nilai gizi suatu produk/bahan pangan terutama total mineral. Kadar abu menunjukkan total mineral yang terkandung dalam bahan tersebut (Apriyantono, 1988).

Berdasarkan analisa keragaman, perbedaan rasio penambahan tepung terigu dan tepung kentang hitam memberikan pengaruh yang berbeda nyata terhadap kadar abu cake kentang hitam. Tingkat perbedaan kadar air akibat pengaruh penambahan tepung terigu dan tepung kentang hitam dapat dilihat pada Gambar 3. 


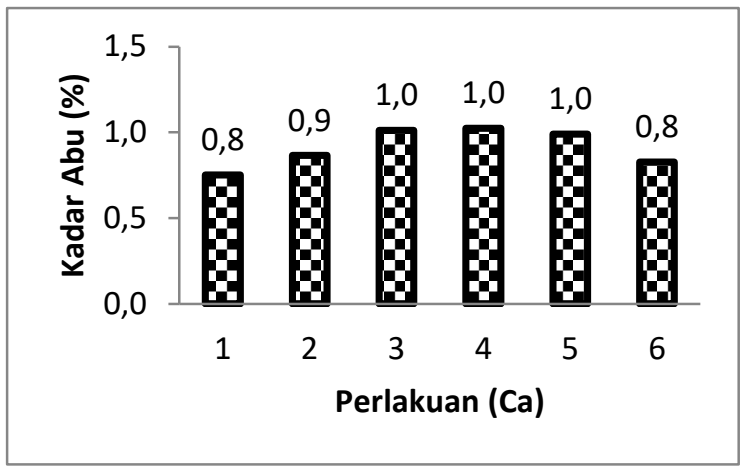

Gambar 3. Pengaruh Penambahan Tepung Terigu dan Tepung Kentang Hitam terhadap Kadar Abu Cake Kentang Hitam

Semakin tinggi penambahan tepung kentang hitam mengakibatkan kenaikan kadar abu pada cake yang dihasilkan. Hal ini dikarenakan kadar abu tepung kentang hitam lebih tinggi (4,44\%) diibandingkan dengan tepung terigu (0,57\%) (Rahman, 2009). Kadar abu yang dihasilkan pada penelitian ini adalah 0,8-1\%. Menurut SNI, Kadar abu biskuit maksimal tadalah $2 \%$ sehingga biskuit yang dihasilkan memenuhi syarat SNI.

\section{c Kadar Protein}

Protein adalah sumber-sumber asam amino yang mengandung unsur $\mathrm{C}, \mathrm{H}, \mathrm{O}$ dan $\mathrm{N}$ yang tidak dimiliki oleh lemak atau karbohidrat. Protein merupakan suatu zat makanan yang amat penting bagi tubuh, karena zat ini disamping berfungsi sebagai bahan bakar dalam tubuh juga berfungsi sebagai zat pembangun dan pengatur (Poedjiadi dan Supriyanti, 2005).

Berdasarkan analisa keragaman, perbedaan rasio penambahan tepung terigu dan tepung kentang hitam memberikan pengaruh yang berbeda nyata terhadap kadar protein cake kentang hitam. Tingkat perbedaan kadar air akibat pengaruh penambahan tepung terigu dan tepung kentang hitam dapat dilihat pada Gambar 4.

Gambar 4 menunjukkan semakin banyak tepung kentang hitam yang ditambahkan maka kadar protein semakin meningkat. Rata-rata kadar protein pada berkisar antara 5,3-7\%. Kandungan protein cake dari hasil penelitian ini telah mencapai standar mutu (SNI 01-38401995) yaitu minimal $3 \%$.
ISSN: 2443-1095

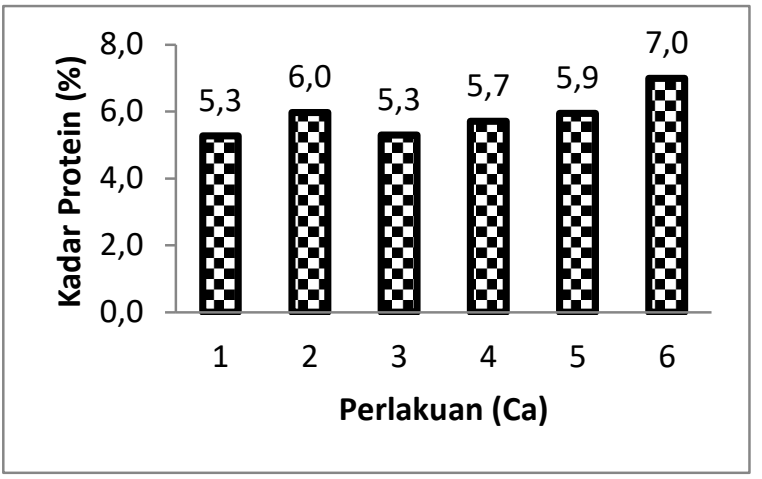

Gambar 4. Pengaruh Penambahan Tepung Terigu dan Tepung Kentang Hitam terhadap Kadar Protein Cake Kentang Hitam

\section{d Warna (Scoring)}

Warna merupakan komponen yang sangat penting dalam menetukan kualitas atau derajat penerimaan dari sesuatu bahan pangan. Warna pada bahan pangan disebabkan oleh berbagai faktor seperti pigmen alami yang terdapat bahan pangan, reaksi kimia (karamelisasi dan oksidasi), dan bahan tambahan pangan.

Berdasarkan analisa keragaman, perbedaan rasio penambahan tepung terigu dan tepung kentang hitam memberikan pengaruh yang berbeda nyata terhadap warna (scoring) cake kentang hitam. Tingkat perbedaan kadar air akibat pengaruh penambahan tepung terigu dan tepung kentang hitam dapat dilihat pada Gambar 5.

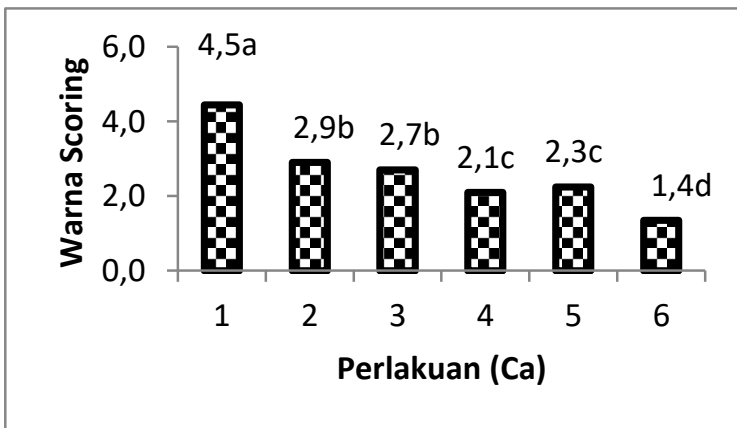

Gambar 5. Pengaruh Penambahan Tepung Terigu dan Tepung Kentang Hitam terhadap Warna (Scoring)Cake Kentang Hitam

Penambahan tepung kentang hitam pada pembuatan cake menghasilkan cake dengan skor semakin rendah yang menunjukkan warna 
Versi Online:

http://www.profood.unram.ac.id/index.php/profood e-ISSN: 2443-3446

semakin gelap (cokelat). Tepung kentang hitam memiliki warna yang lebih gelap daripada tepung terigu.

Di samping karena penggunaan tepung tempe, warna kecokelatan pada roti juga dihasilkan oleh reaksi Maillard. Reaksi Maillard merupakan reaksi browning non enzimatis yang terjadi antara gula pereduksi dengan asam amino yang menghasilkan warna kecokelatan pada bahan makanan ketika mengalami proses pemanasan (Winarno, 2004).

\section{e Tekstur (Hedonic)}

Tekstur merupakan sifat yang sangat penting, baik dalam makanan segar maupun hasil olahan. Tekstur termasuk dalam salah satu faktor yang mempengaruhi penerimaan konsumen terhadap produk pangan. Tekstur bahan pangan dipengaruhi oleh komposisi bahan kimia dan sifat fisik atau mekanis bahan pangan (deMan, 1997).

Berdasarkan analisa keragaman, perbedaan rasio penambahan tepung terigu dan tepung kentang hitam memberikan pengaruh yang berbeda nyata terhadap tekstur (hedonic) cake kentang hitam. Tingkat perbedaan kadar air akibat pengaruh penambahan tepung terigu dan tepung kentang hitam dapat dilihat pada Gambar 6.

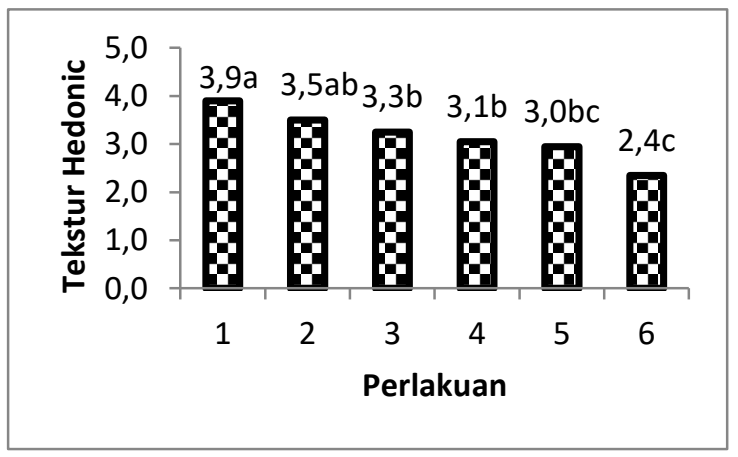

Gambar 6. Pengaruh Penambahan Tepung Terigu dan Tepung Kentang Hitam terhadap Tekstur (Hedonic) Cake Kentang Hitam

Tekstur cake kentang hitam pada penelitian ini memiliki tingkat kesukaan suka hingga agak tidak suka. Tingkat kesukaan tertinggi diperoleh pada perlakuan dengan $100 \%$ tepung terigu sedangkan skor terendah pada
ISSN: 2443-1095

perlakuan penambahan tepung kentang hitam $50 \%$ dengan tekstur padat dan agak kasar. Hal ini disebabkan oleh panelis belum terbiasa mengkonsumsi cake yang dibuat dari tepung selain tepung terigu. Tekstur cake kentang hitam dipengaruhi oleh rasio amilosa amilopektin pada tepung. Tepung kentang hitam memiliki 32\% amilosa. Kandungan amilosa yang tinggi menyebabkan tekstur kaku dan padat pada makanan.

\section{f Rasa (Hedonic)}

Rasa merupakan aspek penting penerimaan bahan pangan oleh konsumen. Penilaian rasa sulit dilakukan secara akurat karena memiliki sifat subyektif, sehingga penilaian tersebut berdasarkan dengan selera konsumen.

Berdasarkan analisa keragaman, perbedaan rasio penambahan tepung terigu dan tepung kentang hitam memberikan pengaruh yang berbeda nyata terhadap rasa (hedonic) cake kentang hitam. Tingkat perbedaan kadar air akibat pengaruh penambahan tepung terigu dan tepung kentang hitam dapat dilihat pada Gambar 7.

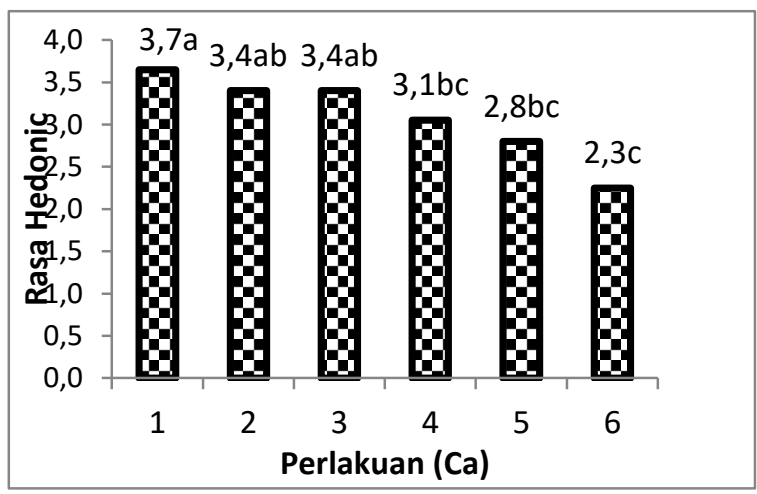

Gambar 7. Pengaruh Penambahan Tepung Terigu dan Tepung Kentang Hitam terhadap Rasa (Hedonic) Cake Kentang Hitam

Pada penelitian ini, semakin banyak tepung hitam yang ditambahkan dalam pembuatan cake menghasilkan cake yang cenderung tidak disukai panelis. Tingkat kesukaan panelis terhadap cake seluruh perlakuan substitusi berbeda nyata dengan cake tanpa substitusi. Rasa cake yang dihasilkan 
Versi Online:

http://www.profood.unram.ac.id/index.php/profood e-ISSN: 2443-3446

dipengaruhi oleh komposisi tepung yang digunakan. Penambahan 50\% tepung kentang hitam memiliki tingkat kesukaan terendah. Hal ini dikarenakan adanya after taste yang tidak disukai panelis. After taste disebabkan oleh hidrolisis asam-asam amino yang terjadi pada reaksi Maillard saat pemanggangan cake (Winarno, 2004).

\section{KESIMPULAN}

Berdasarkan hasil analisa dan pembahasan maka dapat disimpulkan bahwa:

1. Penambahan tepung kentang hitam menyebabkan penurunan kadar air, peningkatan kadar abu, dan kadar protein cake.

2. Semua perlakuan menghasilkan cake yang sesuai standar SNI.

3. Penambahan tepung kentang sampai $10 \%$ menghasilkan cake yang disukai panelis dari segi tekstur, warna, dan rasa.

4. Semakin banyak tepung kentang hitam yang ditambahkan menghasilkan cake yang cenderung tidak disukai panelis.

\section{DAFTAR PUSTAKA}

Andarwulan, N., Kusnandar F., dan Herawati, D. 2011. Analisis Pangan. Dian Rakyat. Jakarta.

Apriyantono, A. 1988. Analisis Pangan. PAU Pangan dan Gizi IPB : Bogor

Cicilia, S. Basuki, E. Prarudiyanto, A. Alamsyah, A. dan Handito, D. $2018 . \quad$ Pengaruh Substitusi Tepung Terigu dengan Tepung Kentang Hitam (Coleus tuberosus) terhadap Sifat Kimia dan Organoleptik Cookies. Pro Food 4(1): 304-310

deMan, J.M. 1997. Kimia Makanan. Institut Teknologi Bandung, Bandung.

Nugraheni, M., Hamidah, S., Aulina, R. 2015. Resistant Starch Tipe 3 Tepung Kentang Hitam (Coleus tuberosus) sebagai Makanan Fungsional untuk Manajemen Penyakit Degeneratif. Universitas Negeri Jogjakarta. Jogjakarta.

Persatuan Ahli Gizi Indonesia. 2009. Tabel Komposisi Pangan Indonesia. Jakarta: PT Elex Media Komputindo
Pro Food (Jurnal Ilmu dan Teknologi Pangan)

Vol 4 No. 2 November 2018

ISSN: 2443-1095

Poedjiadi dan Supriyanti. 2005. Dasar-dasar Biokimia. Jakarta: UI Press.

Rahmayuni. Pato, U. Johan, V.S., Solihin, M.A., 2018. Substitusi Tepung Terigu Dengan Pati Sagu dalam Proses Pembuatan Cake. Gorontalo Agriculture Technology Journal 1(1): $1-9$

Rahman, S. 2009. Formulasi Tepung Kentang Hitam (Solenostemon rotundifolius) dan Tepung Terigu terhadap Beberapa Komponen Mutu Roti Tawar. Universitas Mataram. Skripsi.

Winarno F.G. 2004. Kimia Pangan dan Gizi. PT Gramedia Pustaka Utama. Jakarta. 